\title{
RIPK1 polymorphisms alter the susceptibility to cervical Cancer among the Uyghur population in China
}

\author{
Zulipiyamu Tuoheti ${ }^{1 \dagger}$, Lili Han ${ }^{1 * \dagger}$, Sulaiya Husaiyin ${ }^{1}$, Xiaoxi Liu², Chunhua Ma ${ }^{1}$ and Mayinuer Niyazi ${ }^{1 *}$
}

\begin{abstract}
Background: RIPK1 (receptor-interacting protein kinase-1) plays a role in cancer development, whereas no clear studies focused on the cervical cancer. The objective of this study was to evaluate the relationship between RIPK1 polymorphisms and cervical cancer risk among the Uyghur population.

Methods: We performed a case-control study including 342 cervical cancer patients and 498 age-matched healthy controls. Four RIPK1 genetic variants (rs6907943, rs2077681, rs9503400 and rs17548629) were genotyped with Agena MassARRAY platform. The associations between RIPK1 polymorphisms and cervical cancer risk were assessed under Binary logistic regression models. False discovery rate (FDR) was used to improve the results reliability.

Results: The results showed rs2077681 was significantly associated with cervical cancer risk under various genetic models (codominant: $\mathrm{OR}=3.14,95 \% \mathrm{Cl}=1.40-7.07, p=0.006$, $\mathrm{FDR}-p=0.018$; recessive: $\mathrm{OR}=3.20,95 \% \mathrm{Cl}=1.43-7.16$, $p=0.005$, FDR-0.018). The stratified analysis indicated that the relationships of rs6907946, rs9503400 and rs 17548629 with cervical cancer risk were statistically significant in the subgroup of clinical stage $(p<0.05)$.

Conclusion: Our findings demonstrated that RIPK1 polymorphisms were associated with cervical cancer susceptibility among the Uyghur population in China, and RIPK1 polymorphisms might be involved in the development of cervical cancer.
\end{abstract}

Keywords: RIPK1, Cervical cancer, Uyghur, Case-control study

\section{Background}

Cervical cancer is the fourth most common cancer in women worldwide, and it remains the leading cause of cancer death for women [1]. It was reported that there were approximately 500,000 new cases of cervical cancer annually and most cases occurred in developing countries [2]. In China, the incidence and mortality of cervical cancer continue to increase, especially among women living in rural [3]. The Uyghur, one of minorities in China, has higher morbidity and mortality of cervical

\footnotetext{
*Correspondence: hanliliabcd@163.com; mayinuer0325666@126.com

${ }^{\dagger}$ Zulipiyamu Tuoheti and Lili Han are co-first author.

'Department of Gynecology, People's Hospital of Xinjiang Uygur Autonomous Region, No 91 Tianqi Road, Urumqi, Xinjiang 830001, China Full list of author information is available at the end of the article
}

cancer than other ethnic groups [4]. However, the mechanism underlying cervical cancer remains unclear. Recently, accumulating evidences indicate that genetic factors play a vital role in the development of cervical cancer. To unveil the genetic susceptibility of cervical cancer, it is important to identify genetic markers that affect the cervical cancer development.

Receptor-interacting protein kinase-1 (RIPK1) gene encodes a member of the receptor- interacting protein family of serine/threonine protein kinases. RIPK1 mediates the upstream of NF-kB signaling and plays a crucial role in inflammation and cell death $[5,6]$. Moreover, RIPK1 was identified as a key effector molecule of necroptosis [7]. Number of evidences suggested that

C C The Author(s). 2020 Open Access This article is licensed under a Creative Commons Attribution 4.0 International License, which permits use, sharing, adaptation, distribution and reproduction in any medium or format, as long as you give appropriate credit to the original author(s) and the source, provide a link to the Creative Commons licence, and indicate if changes were made. The images or other third party material in this article are included in the article's Creative Commons licence, unless indicated otherwise in a credit line to the material. If material is not included in the article's Creative Commons licence and your intended use is not permitted by statutory regulation or exceeds the permitted use, you will need to obtain permission directly from the copyright holder. To view a copy of this licence, visit http://creativecommons.org/licenses/by/4.0/. The Creative Commons Public Domain Dedication waiver (http://creativecommons.org/publicdomain/zero/1.0/) applies to the data made available in this article, unless otherwise stated in a credit line to the data. 
necroptosis might take part in the regulation of cancer by pro-inflammatory cytokine production and antitumor immune response [8]. It has been reported that RIPK1 is implicated in some diseases, such as chronic periodontitis [9], liver diseases, and cancers [10]. In mouse models of liver injury, several studies highlighted the importance of RIPK1 in regulating hepatocyte apoptosis through distinct kinase functions [11]. Additionally, genetic variants of RIPK1 may alter the ability of the gene to bind substance, activate transcription and induce apoptosis [12, 13]. Evidences have suggested RIPK1 polymorphisms could be a possible biomarker in colorectal cancer [12]. For example, Chae et al. showed RIPK1 polymorphism was associated with increased risk of colorectal cancer and poorer prognosis of colorectal cancer patients [14]. Nonetheless, the role of RIPK1 polymorphisms has not been confirmed in cervical cancer.

Therefore, to further explore the role of RIPK1 polymorphisms in cervical cancer, we conducted a casecontrol study to assess the impact of RIPK1 polymorphisms in cervical cancer susceptibility among the Uyghur population in China.

\section{Methods}

\section{Study population}

A total of 342 newly diagnosed and histologically confirmed cervical cancer patients were consecutively recruited from People's Hospital of Xinjiang Uygur Autonomous Region. During the same period, we randomly chosen healthy controls who underwent the health examination in People's Hospital of Xinjiang Uygur Autonomous Region. The healthy controls were matched with patients in age. All participators were Uyghur population living in Xin'jiang Province of China. Individuals with cancer history, viral infection, diabetes or cardiovascular diseases were excluded in this study. Written informed consent was obtained from each participant before the sample collection. The study was approved by the Committee for Ethical Affairs of People's Hospital of Xinjiang Uygur Autonomous Region, and study was performed according to the declaration of Helsinki.

\section{SNP selection and genotyping}

Candidate SNPs of RIPK1 gene were selected from previous studies, and preliminary analysis of RIPK1 polymorphism was done using the 1000 Genomes database with minor allele frequency (MAF) larger than 0.05 [15]. Genomic DNA was extracted from peripheral blood samples via a blood DNA kit (GoldMag Co. Ltd., Xi'an, China), and quantified with Nanodrop 2000 (Thermo Scientific, Waltham, Massachusetts, USA). MassARRAY Assay Design 3.0 software was applied for primers design (Table 1). The SNP genotyping was performed using MassARRAY iPLEX platform (Agena Bioscience, San Diego, CA, USA) according to the manufacturer's instructions [16]. Finally, the genotyping results were managed and outputted by Agena Bioscience TYPER version 4.0 software.

\section{Statistical analysis}

All data were analyzed using the SPSS 22.0 software (IBM ${ }^{\circ}$, Armonk, New York, USA). We used Student's $t$ test for continuous variables to evaluate the difference of characteristics between two groups [17]. The HardyWeinberg equilibrium (HWE) values were calculated for the SNPs in the healthy control using Fisher exact test. The differences between cases and controls in the frequency of the alleles and genotypes were evaluated by Chi-square analysis. The functions of candidate SNPs were predicted by HaploReg v4.1. The association between genetic variants and cervical cancer risk was assessed by odd ratios (OR) and 95\% confidence interval (CI) from Binary logistic regression analyses in genetic models [18]. Age was regarded as a covariate in the logistic regression analysis. Then, we used the Haploview software (version 4.2) and the PLINK software to analyze linkage disequilibrium (LD) and haplotype. All tests were two-sided and the statistical significance was set at $p<0.05$. False discovery rate (FDR) was used to correct $p$ values.

\section{Results}

Characteristics of 840 subjects were summarized in Table 2. A total of 342 cervical cancer patients and 498 healthy controls were enrolled with mean ages of $43.27 \pm 11.78$ and $43.46 \pm 13.03$ years, respectively. There was no significant difference in age distribution between cases and controls. According the 2009 FIGO staging system, we divided 342 cervical cancer cases into different clinical stages, 132 cases (39\%) were in stage I and II, 80 cases $(23 \%)$ were in stage III and IV.

Table 1 Primer sequences used for this study

\begin{tabular}{lllll}
\hline SNP & First-PCRP & Second-PCRP & UEP_DIR & UEP_SEQ \\
\hline rs6907943 & ACGTTGGATGACCAGGTGTTGGAGTTCAGC & ACGTTGGATGGGTGTTGTTTGCAGCTCGT & F & tgtgTGCAGCTCGTTAGCAT \\
rs2077681 & ACGTTGGATGGTGAATTAACTGCACTGGG & ACGTGGATGAACCTCGAGGACATCATGCC & $R$ & ggggtACATCATGCCAAGTGGA \\
rs9503400 & ACGTTGGATGAGTAAGTGCTCAGTAAACGG & ACGTTGGATGTGCTCAAGGCTGTCTAGGTG & $R$ & ggagGGCTGTCTAGGTGTTCTTG \\
rs17548629 & ACGTTGGATGTCAACAGTATCAGCCCTGAG & ACGTGGATGTGGCATTCTGGTACCTTCAC & F & cCcCTCACCCAGCCTGAGTG \\
\hline
\end{tabular}


Table 2 Characteristics of the cervical cancer patients and healthy controls in this study

\begin{tabular}{|c|c|c|c|}
\hline Characteristics & Cervical cancer cases $(\boldsymbol{N}=342)$ & Healthy controls $(\boldsymbol{N}=498)$ & $\boldsymbol{P}$ Value \\
\hline Age (year, mean \pm SD) & $43.27 \pm 11.78$ & $43.46 \pm 13.03$ & 0.832 \\
\hline$>43$ & $176(51 \%)$ & $263(53 \%)$ & \\
\hline$\leq 43$ & $166(49 \%)$ & $235(47 \%)$ & \\
\hline \multicolumn{4}{|l|}{ Stage (\%) } \\
\hline | || & $132(39 \%)$ & & \\
\hline III IV & $80(23 \%)$ & & \\
\hline Absence & $130(38 \%)$ & & \\
\hline
\end{tabular}

SD Standard deviation

Detailed information of RIPK1 polymorphisms, including chromosome, position, allele, genotype and allele distribution, MAF and HWE $p$ value were listed in Table 3. The distribution frequencies of four SNPs were in HWE $(p>0.05)$. HaploReg showed that RIPK1 polymorphisms were related to the regulations of Enhancer histone marks, Motifs changed, and Selected eQTL hits. The relationship between RIPK1 polymorphisms and cervical cancer risk was shown in Table 4. Compared with the healthy controls, the individuals who carried CC genotype of rs2077681 had higher risk of cervical cancer (codominant: $\mathrm{OR}=3.14,95 \% \mathrm{CI}=1.40-7.07, p=0.006$; recessive: $\mathrm{OR}=$ $3.20,95 \% \mathrm{CI}=1.43-7.16, p=0.005)$. FDR analysis verified the reliability of these results (codominant: FDR- $p=0.018$; recessive: FDR- $p=0.018$ ). There were no significant associations between other SNPs and cervical cancer risk in this study $(p>0.05)$.
We then performed stratification analysis on the association of RIPK1 polymorphisms with cervical cancer susceptibility (Table 5). In the subgroup of age $>43$ years, individuals carrying the genotype CC in rs2077681 (codominant: $\mathrm{OR}=3.38,95 \% \mathrm{CI}=1.15-9.99, p=0.027$; recessive: $\mathrm{OR}=3.46,95 \% \mathrm{CI}=1.18-10.15, p=0.024)$ and TT in rs17548629 (codominant: $\mathrm{OR}=3.99,95 \% \mathrm{CI}=$ $1.04-15.32, p=0.044$; recessive: $\mathrm{OR}=4.09,95 \% \mathrm{CI}=1.07-$ 15.63, $p=0.040$ ) were more likely to suffer from cervical cancer, whereas FDR analysis showed the strong linkages of rs2077681 and rs17548629 with cervical cancer may not be reliable (FDR- $p>0.05$ ). Moreover, we found that rs6907943 and rs17548629 exerted protective roles in higher grade cervical cancer among Uyghur population (rs6907943, allele: $\mathrm{OR}=0.47,95 \% \mathrm{CI}=0.24-0.90, p=$ 0.021; dominant: $\mathrm{OR}=0.46,95 \% \mathrm{CI}=0.23-0.93, p=0.031$; log-additive: $\mathrm{OR}=0.46,95 \% \mathrm{CI}=0.23-0.89, \quad p=0.022$;

Table 3 Detail information of the RIPK1 gene polymorphisms

\begin{tabular}{|c|c|c|c|c|c|c|c|c|c|c|c|c|}
\hline SNP & Chromosome & $\mathrm{BP}$ & Alleles & Group & Genotyp & & & Allele & & MAF & HWE & HaploReg \\
\hline \multirow[t]{3}{*}{ rs6907943 } & \multirow[t]{3}{*}{6} & \multirow[t]{3}{*}{$3,078,032$} & \multirow[t]{3}{*}{$\mathrm{A} / \mathrm{C}$} & & $\mathrm{CC}$ & CA & AA & C & A & & & \multirow{3}{*}{$\begin{array}{l}\text { Enhancer histone marks, } \\
\text { Motifs changed, Selected } \\
\text { eQTL hits }\end{array}$} \\
\hline & & & & Control & $\begin{array}{l}13 \\
(2.62 \%)\end{array}$ & $\begin{array}{l}129 \\
(25.96 \%)\end{array}$ & $\begin{array}{l}355 \\
(71.42 \%)\end{array}$ & $\begin{array}{l}155 \\
(15.59 \%)\end{array}$ & $\begin{array}{l}839 \\
(84.41 \%)\end{array}$ & 0.156 & 0.734 & \\
\hline & & & & Case & $\begin{array}{l}15 \\
(4.40 \%)\end{array}$ & $\begin{array}{l}77 \\
(22.58 \%)\end{array}$ & $\begin{array}{l}249 \\
(73.02 \%)\end{array}$ & $\begin{array}{l}107 \\
(15.69 \%)\end{array}$ & $\begin{array}{l}575 \\
(84.31 \%)\end{array}$ & 0.157 & & \\
\hline \multirow[t]{3}{*}{ rs2077681 } & \multirow[t]{3}{*}{6} & \multirow[t]{3}{*}{$3,085,866$} & \multirow[t]{3}{*}{$\mathrm{A} / \mathrm{G}$} & & $\mathrm{CC}$ & $C T$ & $\pi$ & C & $\mathrm{T}$ & & & \multirow{3}{*}{$\begin{array}{l}\text { Motifs changed, Selected } \\
\text { eQTL hits }\end{array}$} \\
\hline & & & & Control & $\begin{array}{l}9 \\
(1.82 \%)\end{array}$ & $\begin{array}{l}140 \\
(28.28 \%)\end{array}$ & $\begin{array}{l}346 \\
(69.90 \%)\end{array}$ & $\begin{array}{l}158 \\
(15.96 \%)\end{array}$ & $\begin{array}{l}832 \\
(84.04 \%)\end{array}$ & 0.160 & 0.313 & \\
\hline & & & & Case & $\begin{array}{l}19 \\
(5.57 \%)\end{array}$ & $\begin{array}{l}89 \\
(26.10 \%)\end{array}$ & $\begin{array}{l}233 \\
(68.33 \%)\end{array}$ & $\begin{array}{l}127 \\
(18.62 \%)\end{array}$ & $\begin{array}{l}555 \\
(81.38 \%)\end{array}$ & 0.186 & & \\
\hline \multirow[t]{3}{*}{ rs9503400 } & \multirow[t]{3}{*}{6} & \multirow[t]{3}{*}{$3,108,673$} & \multirow[t]{3}{*}{$A / G$} & & AA & $A G$ & GG & A & G & & & \multirow{3}{*}{$\begin{array}{l}\text { Enhancer histone marks, } \\
\text { Motifs changed }\end{array}$} \\
\hline & & & & Control & $\begin{array}{l}1 \\
(0.20 \%)\end{array}$ & $\begin{array}{l}47 \\
(9.44 \%)\end{array}$ & $\begin{array}{l}450 \\
(90.36 \%)\end{array}$ & $\begin{array}{l}49 \\
(4.92 \%)\end{array}$ & $\begin{array}{l}947 \\
(95.08 \%)\end{array}$ & 0.051 & 1.000 & \\
\hline & & & & Case & $\begin{array}{l}3 \\
(0.88 \%)\end{array}$ & $\begin{array}{l}39 \\
(11.40 \%)\end{array}$ & $\begin{array}{l}300 \\
(87.72 \%)\end{array}$ & $\begin{array}{l}45 \\
(6.58 \%)\end{array}$ & $\begin{array}{l}639 \\
(93.42 \%)\end{array}$ & 0.066 & & \\
\hline \multirow[t]{3}{*}{ rs17548629 } & \multirow[t]{3}{*}{6} & \multirow[t]{3}{*}{$3,114,223$} & \multirow[t]{3}{*}{$\mathrm{C} / \mathrm{T}$} & & $\Pi$ & $\mathrm{TC}$ & CC & $\mathrm{T}$ & C & & & \multirow[t]{3}{*}{ Motifs changed } \\
\hline & & & & Control & $\begin{array}{l}9 \\
(1.81 \%)\end{array}$ & $\begin{array}{l}122 \\
(24.50 \%)\end{array}$ & $\begin{array}{l}367 \\
(73.69 \%)\end{array}$ & $\begin{array}{l}140 \\
(14.06 \%)\end{array}$ & $\begin{array}{l}856 \\
(85.94 \%)\end{array}$ & 0.141 & 0.855 & \\
\hline & & & & Case & $\begin{array}{l}10 \\
(2.92 \%)\end{array}$ & $\begin{array}{l}72 \\
(21.05 \%)\end{array}$ & $\begin{array}{l}260 \\
(76.03 \%)\end{array}$ & $\begin{array}{l}92 \\
(13.45 \%)\end{array}$ & $\begin{array}{l}592 \\
(86.55 \%)\end{array}$ & 0.134 & & \\
\hline
\end{tabular}


Table 4 The association of RIPK1 gene polymorphisms with cervical cancer susceptibility in Uygur population

\begin{tabular}{|c|c|c|c|c|c|c|}
\hline SNP & Model & Allele/Genotype & Frequency (Control/Case) & OR $(95 \% \mathrm{Cl})$ & $\boldsymbol{P}$ Value & FDR-p Value \\
\hline \multirow[t]{10}{*}{ rs6907943 } & \multirow[t]{2}{*}{ Allele } & $C$ & $15.59 \% / 15.69 \%$ & $1.01(0.77-1.32)$ & 0.958 & 0.958 \\
\hline & & $A$ & $84.41 \% / 84.31 \%$ & 1.00 & & \\
\hline & \multirow[t]{3}{*}{ Codominant } & $\mathrm{CC}$ & $2.62 \% / 4.40 \%$ & $1.65(0.77-3.52)$ & 0.199 & 0.597 \\
\hline & & CA & $25.96 \% / 22.58 \%$ & $0.85(0.61-1.18)$ & 0.333 & 0.666 \\
\hline & & AA & $71.42 \% / 73.02 \%$ & 1.00 & & \\
\hline & \multirow[t]{2}{*}{ Dominant } & CC-CA & $28.58 \% / 26.98 \%$ & $0.92(0.68-1.26)$ & 0.616 & 0.924 \\
\hline & & AA & $71.42 \% / 73.02 \%$ & 1.00 & & \\
\hline & \multirow[t]{2}{*}{ Recessive } & CC & $2.62 \% / 4.40 \%$ & $1.72(0.81-3.65)$ & 0.162 & 0.597 \\
\hline & & CA-AA & $97.38 \% / 95.60 \%$ & 1.00 & & \\
\hline & \multicolumn{3}{|l|}{ Log-additive } & $1.01(0.78-1.31)$ & 0.956 & 0.958 \\
\hline \multirow[t]{10}{*}{ rs2077681 } & \multirow[t]{2}{*}{ Allele } & $C$ & $15.96 \% / 18.62 \%$ & $1.21(0.93-1.56)$ & 0.155 & 0.245 \\
\hline & & $\mathrm{T}$ & $84.04 \% / 81.38 \%$ & 1.00 & & \\
\hline & \multirow[t]{3}{*}{ Codominant } & $\mathrm{CC}$ & $1.82 \% / 5.57 \%$ & $3.14(1.40-7.07)$ & 0.006 & 0.018 \\
\hline & & $\mathrm{CT}$ & $28.28 \% / 26.10 \%$ & $0.94(0.69-1.29)$ & 0.711 & 0.711 \\
\hline & & $\pi$ & $69.90 \% / 68.33 \%$ & 1.00 & & \\
\hline & \multirow[t]{2}{*}{ Dominant } & $\mathrm{CC}-\mathrm{CT}$ & $30.10 \% / 31.67 \%$ & $1.08(0.80-1.45)$ & 0.634 & 0.711 \\
\hline & & $\pi$ & $69.90 \% / 68.33 \%$ & 1.00 & & \\
\hline & \multirow[t]{2}{*}{ Recessive } & $\mathrm{CC}$ & $1.82 \% / 5.57 \%$ & $3.20(1.43-7.16)$ & 0.005 & 0.018 \\
\hline & & CT-TT & $98.18 \% / 94.43 \%$ & 1.00 & & \\
\hline & \multicolumn{3}{|l|}{ Log-additive } & $1.20(0.93-1.54)$ & 0.163 & 0.245 \\
\hline \multirow[t]{10}{*}{ rs9503400 } & \multirow[t]{2}{*}{ Allele } & A & $4.92 \% / 6.58 \%$ & $1.36(0.90-2.07)$ & 0.146 & 0.271 \\
\hline & & G & $95.08 \% / 93.42 \%$ & 1.00 & & \\
\hline & \multirow[t]{3}{*}{ Codominant } & AA & $0.20 \% / 0.88 \%$ & $4.46(0.46-43.25)$ & 0.197 & 0.271 \\
\hline & & GA & $9.44 \% / 11.40 \%$ & $1.25(0.79-1.95)$ & 0.339 & 0.339 \\
\hline & & GG & $90.36 \% / 87.72 \%$ & 1.00 & & \\
\hline & \multirow[t]{2}{*}{ Dominant } & AA-GA & $9.64 \% / 12.28 \%$ & $1.31(0.85-2.04)$ & 0.226 & 0.271 \\
\hline & & GG & $90.36 \% / 87.72 \%$ & 1.00 & & \\
\hline & \multirow[t]{2}{*}{ Recessive } & $\mathrm{AA}$ & $0.20 \% / 0.88 \%$ & $4.36(0.45-42.26)$ & 0.203 & 0.271 \\
\hline & & GA-GG & $99.8 \% / 99.12 \%$ & 1.00 & & \\
\hline & \multicolumn{3}{|l|}{ Log-additive } & $1.35(0.89-2.03)$ & 0.155 & 0.271 \\
\hline \multirow[t]{10}{*}{ rs17548629 } & \multirow[t]{2}{*}{ Allele } & $\mathrm{T}$ & $14.06 \% / 13.45 \%$ & $0.95(0.72-1.26)$ & 0.724 & 0.724 \\
\hline & & $C$ & $85.94 \% / 86.55 \%$ & 1.00 & & \\
\hline & \multirow[t]{3}{*}{ Codominant } & $\pi$ & $1.81 \% / 2.92 \%$ & $1.57(0.63-3.92)$ & 0.334 & 0.663 \\
\hline & & $\mathrm{TC}$ & $24.50 \% / 21.05 \%$ & $0.83(0.60-1.16)$ & 0.277 & 0.663 \\
\hline & & $\mathrm{CC}$ & $73.69 \% / 76.03 \%$ & 1.00 & & \\
\hline & \multirow[t]{2}{*}{ Dominant } & TT-TC & $26.31 \% / 23.97 \%$ & $0.88(0.64-1.21)$ & 0.442 & 0.663 \\
\hline & & $\mathrm{CC}$ & $73.69 \% / 76.03 \%$ & 1.00 & & \\
\hline & \multirow[t]{2}{*}{ Recessive } & $\pi$ & $1.81 \% / 2.92 \%$ & $1.64(0.66-4.07)$ & 0.289 & 0.663 \\
\hline & & TC-CC & $98.19 \% / 97.08 \%$ & 1.00 & & \\
\hline & \multicolumn{3}{|l|}{ Log-additive } & $0.95(0.72-1.26)$ & 0.724 & 0.724 \\
\hline
\end{tabular}

SNP Sing nucleotide polymorphism, OR Odds ratios, $\mathrm{Cl}$ Confidence intervals, FDR False discovery ratel Bold italics indicates the SNP with statistical significance $(p<0.05)$ 


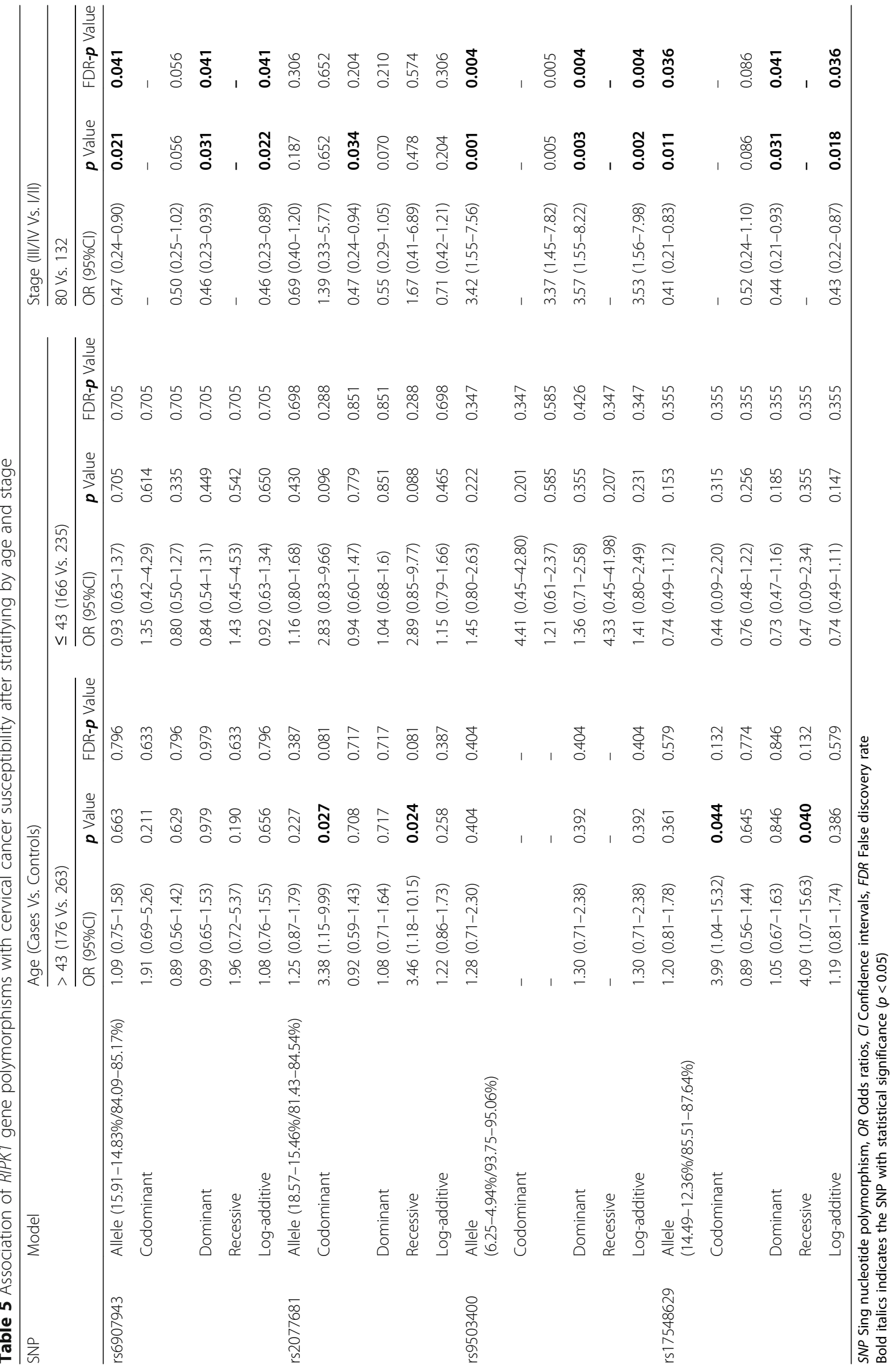


rs17548629, allele: $\mathrm{OR}=0.41,95 \% \mathrm{CI}=0.21-0.83, p=$ 0.011; dominant: $\mathrm{OR}=0.44,95 \% \mathrm{CI}=0.21-0.93, p=0.031$; log-additive: $\mathrm{OR}=0.43,95 \% \mathrm{CI}=0.22-0.87, p=0.018)$. However, allele $(\mathrm{OR}=3.42,95 \% \mathrm{CI}=1.55-7.56, \quad p=$ $0.001)$, dominant $(\mathrm{OR}=3.57,95 \% \mathrm{CI}=1.55-8.22, p=$ $0.003)$ and log-additive $(\mathrm{OR}=3.53,95 \% \mathrm{CI}=1.56-7.98$, $p=0.002$ ) models revealed the remarkable associations of rs9503400 and increased risk of stage III/IV cervical cancer. Haplotype analysis did not show blocks in RIPK1 polymorphisms (Supplemental Figure 1), and no associations with risk of cervical cancer.

\section{Discussion}

In the present study, we found strong linkages between RIPK1 polymorphisms and cervical cancer susceptibility. To our knowledge, it is the first study to provide the evidence that RIPK1 polymorphisms are associated with cervical cancer risk among the Uygur population in China.

$R I P K 1$, also known as RIP1, is a main adaptor kinase in several signaling pathways inducing tumor cell apoptosis by activing NF- $\mathrm{B}[19,20]$. The overexpression of RIPK1 was associated with a poor prognosis for brain tumors based on altering the apoptosis [21]. Besides that, smac mimetics are considered as potential cancer therapeutics. It has been demonstrated that RIPK1 was involved in SM-induced cell death in breast and lung cancer cell $[22,23]$. Chae et al. found that RIPK1 polymorphism is an indicator of hepatic injury and a promising prognostic biomarker for cancer development, whereas RIPK1 polymorphisms were not associated with rectal cancer [12]. This difference may be attributed to the biologic differences of RIPK1 polymorphisms. Genetic mutations are dependent on cancer site, etiology of cancer, study population and environmental factors. Moreover, cancer is a heterogeneous disease in terms of risk factor, tumor features and somatic alterations [24, 25]. In our study, RIPK1 rs2077681was remarkablely related to cervical cancer risk after adjustment. Specially, it was observed that age and stage of cervical cancer could affect the relationship between four RIPK1 polymorphisms and cervical cancer among the Uyghur population.

Many risks are related to the incidence of cervical cancer, including individuals' characteristics, oncogenic HPV infections, smoking habits and other disease [26]. As we all know, aging is an obvious risk for the development of cancer [27]. Hence, we explored the association between RIPK1 polymorphisms and cervical cancer susceptibility stratified by age. We did not observe significant associations between RIPK1 polymorphisms and risk of cervical cancer. It suggests that age is not an important factor for the association of RIPK1 polymorphisms and cervical cancer. The expression or mutation of RIPK1 polymorphisms with aging would not be deleterious for cervical cancer. Furthermore, we found the genetic variants in RIPK1 contribute to different clinical outcomes among cervical cancer patients, which suggests the necessity of the study on genetic susceptibility. RIPK1 rs6907943 and rs17548629 were protective factors for the higher-grade (III, IV) cervical cancer among the Uyghur population by stratification analysis. However, rs9503400 increased the risk for cervical cancer patients during stage III and IV. It may be attributed to the regulation of RIPK1 polymorphisms on Enhancer histone marks and Motifs changed. These results indicated the impact of candidate SNPs on cervical cancer risk, providing evidences for prevention, diagnosis and personalized treatment of cervical cancer.

There are several limitations in the present study. First, the limited sample size, more samples are needed to validate our findings. Second, we did not analyze the impact of other risk factors on the cervical cancer susceptibility due to the lack of information on participates. Third, some patients were lacking clinical stage information, it may influence the stratified analysis results. Finally, although we identified the close associations between RIPK1 polymorphisms and cervical cancer risk, the underlying mechanism is still unclear. Further studies are required to perfect our study.

\section{Conclusion}

In conclusion, our study reveals that RIPK1 polymorphisms alter the susceptibility to cervical cancer among the Uyghur population, and it suggests that RIPK1 polymorphisms exert significant roles in cervical cancer development. Large-scale studies of different ethnic groups are required to validate the genetic association and functional studies are also needed to unveil the underlying mechanism of the RIPK1 polymorphisms on cervical carcinogenesis.

\section{Supplementary information}

Supplementary information accompanies this paper at https://doi.org/10. 1186/s12885-020-06779-4.

Additional file 1: Supplemental Figure S1. Haplotype block map for the SNPs of RIPK1. The LD between two SNPs is standardized by D'.

\begin{abstract}
Abbreviations
RIPK1: Receptor-interacting protein kinase-1); MAF: Minor allele frequency; HWE: Hardy-Weinberg equilibrium; OR: Odd ratios; Cl: Confidence interval; LD: Linkage disequilibrium; FDR: False discovery rate
\end{abstract}

Acknowledgements

We thank the individual who participated in this study.

Authors' contribution

MN, ZT and LH designed this study. LH, SH and MN performed the study, $\mathrm{CM}$ collected samples, $\mathrm{XL}$ wrote the draft. MN revised the draft. All authors have read and approved the manuscript. 


\section{Funding}

This study was supported by the Xinjiang Tianshan Youth program in 2017 (2017Q008). The fund mentioned was used for the design of the study, the collection, analysis, and interpretation of the data as well as the writing of the manuscript. The funder of the Xinjiang Tianshan Youth program in 2017 (2017Q008) is Lili Han who is responsible for designing and performing this study.

\section{Availability of data and materials}

The datasets used and/or analyzed during the current study available from the corresponding author on reasonable request.

\section{Ethics approval and consent to participate}

Written informed consent was obtained from each participant before the sample collection. The study was approved by the Committee for Ethical Affairs of People's Hospital of Xinjiang Uygur Autonomous Region, and was performed according to the declaration of Helsinki.

\section{Consent for publication}

Not applicable.

\section{Competing interests}

All authors certify that we have no conflict of interest in this study.

\section{Author details}

'Department of Gynecology, People's Hospital of Xinjiang Uygur Autonomous Region, No 91 Tianqi Road, Urumqi, Xinjiang 830001, China. ${ }^{2}$ Key Laboratory of Resource Biology and Biotechnology in Western China, (Northwest University), Ministry of Education, Xi'an, Shaanxi 710069, P. R. China.

Received: 20 September 2019 Accepted: 23 March 2020 Published online: 09 April 2020

\section{References}

1. Ferlay J, Soerjomataram I, Dikshit R, Eser S, Mathers C, Rebelo M, Parkin DM, Forman D, Bray F. Cancer incidence and mortality worldwide: sources, methods and major patterns in GLOBOCAN 2012. Int J Cancer. 2015;136(5): E359-86.

2. Xu C, Shao Y, Xia T, Yang Y, Dai J, Luo L, Zhang X, Sun W, Song H, Xiao B. IncRNA-AC130710 targeting by miR-129-5p is upregulated in gastric cancer and associates with poor prognosis. Tumour Biol J Int Soc Oncodev Biol Med. 2014;35(10):9701-6.

3. Zhu S, Weng J, Zhu HY. Study on the prokaryotic expression of human papillomavirus type16 E7 protein and its role in cervical cancer treatment. Mod Prev Med. 2009;36(22):4317.

4. Jun-Qi M, Hatila T, Shu-Juan J, Jian-He Z, Jing-Bao X, Ayshamgul H. Functional Role of NRF2 in Cervical Carcinogenesis. PLoS One. 2015;10(8): e0133876.

5. Brenner D, Blaser H, Mak TW. Regulation of tumour necrosis factor signalling: live or let die. Nat Rev Immunol. 2015;15(6):362-74.

6. Chen G, Cheng X, Zhao M, Lin S, Lu J, Kang J, Yu X. RIP1-dependent bid cleavage mediates TNFa-induced but Caspase-3-independent cell death in L929 fibroblastoma cells. Apoptosis. 2015;20(1):92-109.

7. Legarda D, Justus SJ, Ang RL, Rikhi N, Li W, Moran TM, Zhang J, Mizoguchi E, Zelic M, Kelliher MA. CYLD proteolysis protects macrophages from TNFmediated auto-necroptosis induced by LPS and licensed by type I IFN. Cell Rep. 2016;15(11):2449-61

8. Meng MB, Wang HH, Cui YL, Wu ZQ, Shi YY, Zaorsky NG, Deng L, Yuan ZY, Lu Y, Wang P. Necroptosis in tumorigenesis, activation of anti-tumor immunity, and cancer therapy. Oncotarget. 2016;7(35):57391-413.

9. Yang J, Zhao Y, Zhang L, Fan H, Qi C, Zhang K, Liu X, Fei L, Chen S, Wang M. RIPK3/MLKL-Mediated Neuronal Necroptosis Modulates the M1/M2 Polarization of Microglia/Macrophages in the Ischemic Cortex. Cereb Cortex. 2018;28:7.

10. Ofengeim D, Yuan J. Regulation of RIP1 kinase signalling at the crossroads of inflammation and cell death. Nat Rev Mol Cell Biol. 2013;14(11):727-36.

11. Nault JC, Galle PR, Marquardt JU. The role of molecular enrichment on future therapies in hepatocellular carcinoma. J Hepatol. 2018;69(1): S016882781830134X

12. Chae YS, Kim JG, Sang KS, Su JL, Kang BW, Moon JH, Park JY, Jeon SW, Bae $\mathrm{HI}$, Choi GS. RIPK1 and CASP7 polymorphism as prognostic markers for survival in patients with colorectal cancer after complete resection. J Cancer Res Clin Oncol. 2011;137(4):705-13.

13. Kondylis V, Kumari S, Vlantis K, Pasparakis M. The interplay of IKK, NF-KB and RIPK 1 signaling in the regulation of cell death, tissue homeostasis and inflammation. Immunol Rev. 2017;277(1):113-27.

14. Chae Y, Kim J, Sohn S, Kim S, Lee S, Moon J, Jeon S, Cho Y, Choi G, Jun S. RIPK1 gene polymorphism as a prognostic marker for survival in patients with colorectal cancer. J Clin Oncol. 2009;27(15_suppl):e15078.

15. Wang J, Chai YL, Wang T, Liu JH, Dai PG, Liu Z. Genetic alterations of PIK3CA and tumor response in patients with locally advanced cervical squamous cell carcinoma treated with cisplatin-based concurrent chemoradiotherapy. Exp Mol Pathol. 2015;98(3):407-10.

16. Dai ZJ, Liu XH, Kang HF, Wang XJ, Jin TB, Zhang SQ, Feng T, Ma XB, Wang $M$, Feng YJ. Genetic variation in metastasis-associated in Colon Cancer-1 and the risk of breast Cancer among the Chinese Han population: a STROBE-compliant observational study. Medicine. 2016;95(6):e2801.

17. Zhou L, He N, Feng T, Geng T, Jin T, Chen C. Association of five single nucleotide polymorphisms at 6q25.1 with breast cancer risk in northwestern China. Am J Cancer Res. 2014;5(8):2467.

18. Xia P, Li B, Geng T, Deng Z, Dang C, Chang D, Kang L, Jin T, Chen C. FGFR2 gene polymorphisms are associated with breast cancer risk in the Han Chinese population. Am J Cancer Res. 2015:5(5):1854-61.

19. Stanger BZ, Leder P, Lee TH, Kim E, Seed B. RIP: a novel protein containing a death domain that interacts with Fas/APO-1 (CD95) in yeast and causes cell death. Cell. 1998;81(4):513-23.

20. Eichholtz-Wirth $\mathrm{H}$, Sagan D. IkB/NF-kB mediated cisplatin resistance in HeLa cells after low-dose $\gamma$-irradiation is associated with altered SODD expression. Apoptosis. 2000;5(3):255-63.

21. Park S, Hatanpaa KJ, Xie Y, Mickey BE, Madden CJ, Raisanen JM, Ramnarain DB, Xiao G, Saha D, Boothman DA. The receptor interacting protein (RIP1) inhibits p53 induction through NF-kB activation and confers a worse prognosis in glioblastoma. Cancer Res. 2009;69(7):2809-16.

22. Roesler S, Eckhardt I, Wolf S, Fulda S. Cooperative TRAIL production mediates IFNa/Smac mimetic-induced cell death in TNFa-resistant solid cancer cells. Oncotarget. 2016;7(4):3709-25.

23. Qin H, Hua T. Interferon- $\gamma$ and Smac mimetics synergize to induce apoptosis of lung cancer cells in a TNFa-independent manner. Cancer Cell Int. 2018;18(1):84.

24. Colbert LH, Hartman TJ, Malila N, Limburg PJ, Pietinen P, Virtamo J, Taylor PR, Albanes D. Physical activity in relation to cancer of the colon and rectum in a cohort of male smokers. Cancer Epidemiol Prev Biomark. 2001; 10(3):265-8.

25. Aamodt R, Jonsdottir K, Andersen SN, Bondi J, Bukholm G, Bukholm IR. Differences in protein expression and gene amplification of cyclins between colon and rectal adenocarcinomas. Gastroenterol Res Pract. 2009;2009:1-9.

26. Seppä K, Pitkäniemi J, Malila N, Hakama M. Age-related incidence of cervical cancer supports two aetiological components: a population-based register study. BJOG Int J Obstet Gynaecol. 2016;123(5):772-8.

27. Xiong WM, Xu QP, Li X, Xiao RD, Cai L, He F. The association between human papillomavirus infection and lung cancer: a system review and meta-analysis. Oncotarget. 2017;8(56):96419-32.

\section{Publisher's Note}

Springer Nature remains neutral with regard to jurisdictional claims in published maps and institutional affiliations.

Ready to submit your research? Choose BMC and benefit from:

- fast, convenient online submission

- thorough peer review by experienced researchers in your field

- rapid publication on acceptance

- support for research data, including large and complex data types

- gold Open Access which fosters wider collaboration and increased citations

- maximum visibility for your research: over $100 \mathrm{M}$ website views per year

At $\mathrm{BMC}$, research is always in progress.

Learn more biomedcentral.com/submission 